\title{
Interplay between air passengers' service quality, satisfaction, loyalty and loyalty programmes in South African owned airlines
}

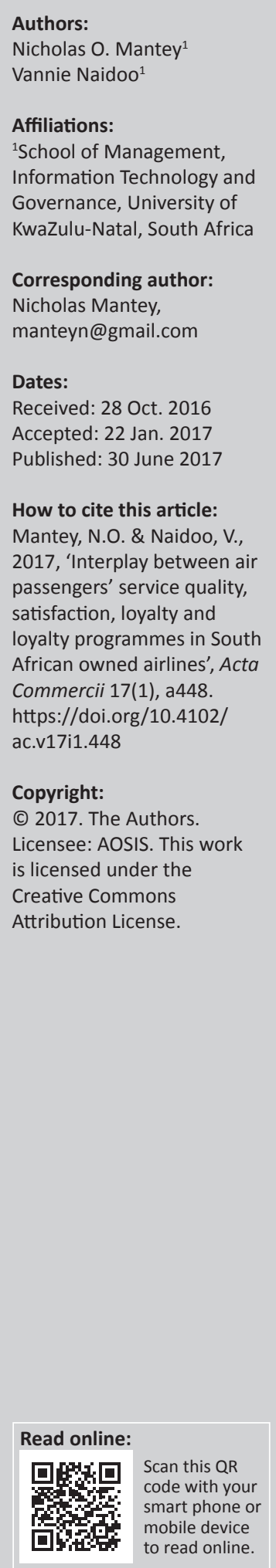

Orientation: Delivering service quality is crucial for the continuous operation and sustainability of South African owned airlines. The term 'South African owned airlines' refers to six South African owned registered airlines, and is used for purpose of anonymity and confidentiality.

Research purpose: The main aim of this study was to examine the interplay between service quality delivery, satisfaction, loyalty programmes and passengers' loyalty to South African owned airlines.

Motivation for the study: Intended to provide insight into quality to society of airline services, the global airline industry in general and the airline industry in South Africa in particular.

Research approach, design and method: A quantitative research approach was adopted, using a cross-sectional (sample survey) method. Empirical data was directly collected by the researchers from 684 passengers at O.R. Tambo International Airport in Johannesburg and King Shaka International Airport in Durban using a non-probability random sampling technique.

Main findings: The study's main findings were that: (1) generally, passengers of South African owned airlines were satisfied with the airlines' service quality and rated such satisfaction as moderate to high. (2) Only $22 \%$ of passengers were part of a loyalty programme. However, in the South African context, loyalty programme membership is not indicative of passengers' loyalty to airlines: $86 \%$ of the respondents stated that they are consistently loyal to the airlines (3). There was no association between passengers' loyalty and frequency of travel. (4) South African passengers have limited choice of airlines; therefore, loyalty and patronage does not lean towards a particular airline.

Practical implications: By offering superior service quality to passengers, South African owned airlines could gain competitive advantage ongoing patronage and loyalty, thus increasing overall profitability.

Contributions: This study provides cognitive information, which management could use to design new marketing strategies to enhance loyalty in the airlines in South Africa and globally.

\section{Introduction}

This article examines service quality, passenger satisfaction, loyalty programmes and passenger loyalty to the South African owned airlines listed in Table 1. As in the global airline marketplace, passengers are the key constituents of the South African airline industry. Therefore, providing service excellence and quality should be the airlines' main fiduciary duty and responsibility. From a passenger's perspective, excellent service quality induces customer satisfaction and future loyalty and patronage. From an airline's perspective, providing service quality promotes competitive advantage and increases the prospect of enjoying ongoing passenger patronage and loyalty (Steven, Dong \& Dresdner 2012:743). In the global airline industry, loyalty or frequent flyer programmes are widely used to build stronger links with customers (Keller 2013:189). The rationale is: 'identifying, maintaining, and increasing the yield from a firm's best customers through long-term, interactive, value-added relationships' (Keller 2013:189).

The rewards offered by frequent flyer programmes include accumulation of flight miles for future redemption against discounted or cheap flight tickets, affiliation with star alliances, special rewards for frequent flyers, hotel accommodation, special holiday packages, car rentals, credit cards and mobile phones. While some airlines faithfully honour their promises, others renege on 
TABLE 1: South African owned airlines.

\begin{tabular}{lll}
\hline Pseudonym & Type of service(s) & Area of operation \\
\hline Airline $G$ & LCA & Domestic \& regional cities \\
Airline $X$ & LCA/TA & $\begin{array}{l}\text { Global, regional \& domestic } \\
\text { cities }\end{array}$ \\
Airline $C$ & LCA & Domestic \& regional cities \\
Airline T & LCA/TA & Domestic \& regional cities \\
Airline Y & TA & Global \\
Airline $Z$ & LCA/TA & Domestic \& regional cities \\
Others & - & - \\
\hline
\end{tabular}

Source: Created by the researcher from Luke and Walters (2013:1-11)

LCA, low cost airlines; TA, traditional airlines.

a, new airlines that were not operating at the time writing this article.

them (Pfeffer 2014:2). Occasionally, loyalty programmes are shrouded in secrecy and lack transparency. The average passenger lacks information on the procedures and rewards, let alone how and when to claim such rewards. Consequently, some passengers are unenthusiastic and sceptical about loyalty programmes. The real benefit of airline loyalty programmes is debatable among passengers, academics and industry players. There are two schools of thought. One holds that loyalty programmes are beneficial to passengers and airlines while the other contends that they are of little value due to failure to follow through on promises. According to Pfeffer (2014:1), 'airline mileage programs are designed to be psychologically attractive, even addictive, to customers ... but as their benefits have decreased, so too has passengers' loyalty'. There is a paucity of research on the interplay between airline service quality, passenger satisfaction and loyalty programmes and passenger loyalty in South Africa. The study thus aimed to (1) evaluate the level of service quality satisfaction in relation to passenger loyalty in the South African airline industry, (2) determine if passengers' membership of loyalty programmes is indicative of loyalty and patronage of South African owned airlines, (3) determine the effect of the gaps in quality service delivery on passengers of South African owned airlines and (4) determine the correlation between frequency of travel and South African owned airlines' loyalty programmes. The study thus contributes to the body of knowledge by examining the subject from a South African perspective.

\section{Theoretical model and hypothesis}

Given the lack of a specific, inclusive model for the airline industry, this study adopted the SERVQUAL and Gaps models to evaluate South African owned airlines. Created by Parasuraman, Zeithaml and Berry (1985:41-50, 1988:12-40), the SERVQUAL model was custom-made to measure service quality expectations and perceptions (Pakdil \& Aydim 2007:227-237). It provides generic observations about service quality evaluation and is designed for applications in various industries (Lo, Wu \& Tsai 2015:169; Metters, King-Metters Pullman \& Walton 2006:185; Naidoo 2015:40-60; Schneider \& White 2004:31). The original 10 SERVQUAL dimensions were 'tangibility, responsiveness, access, competence, reliability, courtesy, communication, credibility, security, and understanding/knowing the customer' (Parasuraman et al. 1985:12-40). However, the dimensions are collapsed into five, which are tangibility, responsiveness, reliability, assurance and empathy (Fitzsimmons \& Fitzsimmons 2011:116; van Iwaarden et al. 2003:919; Naidoo \& Mutinta 2014:219; Shahin 2006:4).

The expectation under the SERVQUAL model (Parasuraman et al. 1985:12-40) is that customers will be happy with the services delivered to them. Therefore, in this study the SERVQUAL and Gaps models (Lovelock \& Wirtz 2011:406; Parasuraman et al. 1985:41-50, 1988:12-40) were deployed to appraise service quality delivery in terms of air passengers' satisfaction. The customer evaluates service quality by determining the (dis)similarity between expected and perceived services (Lo et al. 2015:169; Shahin 2006:2). Customer satisfaction is measured as either negative or positive depending on the gaps between the expected and the perceived service rendered by the firm (Lo et al. 2015:169; Shahin 2006:2). While the SERVQUAL model is used extensively as a diagnostic model for evaluating service quality for customers (Sahney, Banwet \& Karunes 2004:143), Ladhari (2009:172) criticised it for certain theoretical, conceptual, operational and empirical deficiencies. In order to provide a proper analysis, the following hypotheses, $H 1$, $H 2, H 3$ and $H 4$, are posed based on the empirical findings of the study, the theoretical models and existing literature on the subject.

H1: There is general service quality satisfaction among passengers of South African owned airlines.

H2: Passengers' membership of loyalty programmes does not guarantee their loyalty and patronage of South African owned airlines.

H3: Service quality gaps in South African owned airlines have no effect on passengers' loyalty and patronage.

H4: There is no significant association between passengers' travel frequency and the loyalty programmes offered by South African owned airlines.

\section{Literature review}

This review examines the relationship between airline services quality, satisfaction, passengers' loyalty and loyalty programmes in the airline industry from a South African perspective. The discussion commences with concepts of service quality. The most general description of service quality is the extent to which service provision satisfies customer requirements or expectations (Wang et al. 2011:419-437; Wisniewiski 2001:380). Parasuraman et al. (1985:41-50, 1988:12-40) considered the divergence between customer expectations of service and the perceived service' in examining service quality. The evidence shows that service quality is an antecedent to customer loyalty from the perspective of airline service quality (Chen \& 'Sunny' Hu 2013:1087; Naumann 2011:21). Chen \& 'Sunny' $\mathrm{Hu}$ (2013:1087) hypothesise that service quality relates positively to customer loyalty. Customer loyalty is considered to be 
a psychological character formed by the sustained satisfaction of the customer coupled with emotional attachment formed with the service provider that leads to a state of willingly and consistently being in the relationship with preference, patronage, and premium. (Rai \& Medha 2013:141)

Kotler and Keller (2012:149) define customer loyalty as 'a deeply held commitment to re-buy or re-patronise a preferred product or service in the future despite situational influences and marketing efforts having the potential to cause switching behaviour'.

According to Piercy (2009), customer loyalty can be examined from two conceptual perspectives: customer satisfaction and customer loyalty. Customer satisfaction is centred on attitude: how customers perceive the quality of the product or the service they receive from the firm (Baker 2013:71; Chikwendu, Ejem \& Ezenwa 2012:117). On the other hand, customer loyalty centres on behaviour - how long the firm keeps the customer and the extent to which the customer patronises the firm's goods and services (Harrison \& Van Hoek 2011:52; Piercy 2009:16). Indeed, customer loyalty is the pillar of viable competitive and sustainable advantage in the service sector (Chen \& 'Sunny' Hu 2013:1087). In view of the fact that there is minimal differentiation in the airline industry that hinges on fares and prices and frequent flyer programmes, airlines rely more on customer loyalty and customer relationship management (CRM) to establish their unique identity or brand (De Meyer \& Mostert 2011:80). This ultimately results in competitive advantage, increased customer loyalty and increased market share (Archana \& Subha 2012:51).

\section{Loyalty and customer satisfaction}

The key driver of customer loyalty is customer satisfaction as a consequence of excellent service quality, which leads to an increased customer base for the service firm (Johnson, Sivadas \& Garbarino 2008:353; Reinartz \& Kuma 2002:86). An exceedingly satisfied customer who is gratified with the services provided by a service firm will possibly become a loyal promoter of the firm; this is applicable to the airline industry (Terblanche 2015:200). Satisfied customers will strengthen their buying blueprint with that service firm while also disseminating positive confirmatory word-of-mouth information to would-be customers about the service provider (Terblanche 2015:200). In contrast, dissatisfied customers deride the service firm, discouraging potential customers; this is one of the factors that contribute to customer switching behaviour (Berndt \& Brink 2004:25). Service firms delivering better quality services to customers gain customer loyalty, enhancing profitability and reducing service failure (Namukasa 2013:529).

According to Steven et al. (2012:743), service firms' profitability may improve through customer repurchase behaviour, which is a consequence of customer satisfaction. Some satisfied passengers may willingly pay higher than normal price for services that are of exceptionally higher quality; this further enhances profitability (Martin, Roman \& Espino 2008:199). Since the profitability of most airlines depends predominantly on customer loyalty, excellent service quality should be pivotal (De Meyer \& Mostert 2011:79). This requires that South African owned airlines constantly re-evaluate the connection between service quality provision and customer satisfaction. Empirical evidence confirms that there is a positive connection between customer satisfaction and customer loyalty (Johnson et al. 2008:353; Mohan, Choi \& Min 2008:265; Namukasa 2013:530). Consequently, airline companies should endeavour to please passengers by avoiding service failure, thus maintaining continuous patronage (Nikbin et al. 2015:240).

\section{Passengers switching loyalty and patronage}

Information empowers passengers to switch loyalty and patronage should they be dissatisfied with any aspect of airline services (Ahadmotlaghi \& Pawar 2012:3; Archana \& Subha 2012:51). 'Consumers are better educated and informed than ever, and they have the tools to verify companies' claims and seek out superior alternatives' (Urban 2004:77-82). Due to the volume of information at their disposal, there is a high probability of passengers switching to other airlines (Mantey 2015:8). Furthermore, some passengers spread negative word-of-mouth information about poor service quality to potential passengers, which may damage the standing of the airline company (Nikbin et al. 2015:340). The competitive nature of the airline industry calls for improved ways of delivering sustainable competitive advantage strategies (Chen \& 'Sunny' Hu 2013:1084, 1086; Siu, Zhang \& Yau 2013:675). A firm's service delivery vision and organisational culture should be designed to ultimately provide customer value to the passenger (De Meyer \& Mostert 2011:42-79; Duchessi 2002:10).

\section{Customer value and airline passengers}

Airline passengers expect to receive valuable services from airlines at all times. Customer value in respect of airlines may be considered as the extent to which the passenger receives value for money after the performance of the service (De Meyer \& Mostert 2011:80; Duchessi 2002:10). This means that the passenger received quality service at a reasonable or low price, the desired service expectation was achieved and the service received was top class and commensurate with the price paid (Zeithaml, Bitner \& Gremler 2006:35). The motivation for air passengers to switch loyalty and patronage to competitors is the desire for service excellence and attainment of customer value (Archana \& Subha 2012:51). Despite the intricacies involved in meeting customers' expectations, airlines should endeavour to satisfy such expectations, because their competiveness and sustainability thrive on passenger satisfaction and customer value or value for money received (Park, Robertson \& Wu 2004:435).

\section{Methods}

The target population for this study consisted of passengers (domestic and international) from the 17400000 people (Airports Company of South Africa[ACSA] 2014:114) who 
annually travelled through the O.R. Tambo Airport in Johannesburg and King Shaka Airport in Durban. In view of the fact that the target population of passengers was large and there was no database on the passengers to delineate specific South African owned airline passengers in the population, a non-probability sampling technique was used (Sekaran \& Bougie 2013:252). This study adopted a quantitative research approach using a cross-sectional (sample survey) method. Convenience sampling is a type of non-probability sampling in which people are sampled because they are 'convenient' sources of data for the researcher (Battaglia \& Lavrakas 2013:149; Sekaran \& Bougie 2013:252).

In convenience sampling the representativeness of the sample is generally less of a concern. ... A researcher may want data collected quickly using a low-cost method that does not involve scientific sampling. (Battaglia \& Lavrakas, 2013:149)

Non-probability techniques were used in similar studies in the South African airline environment by Campbell and Vigar-Ellis (2012:97-119) and Mostert, De Meyer and van Rensburg (2009:118-140); this justifies its adoption for the current study. Primary data were directly collected from 684 passengers at O.R. Tambo International Airport in Johannesburg and King Shaka International Airport in Durban. A five-point Likert-scale questionnaire (instrument) was developed that was adapted from the SERVQUAL model, with closed-ended statements and questions. The survey questionnaires were personally distributed by the researchers to passengers who confirmed they had travelled with South African owned airlines in the past months. Effort was also made to avoid double counting, by not sampling passengers twice in the respective airports. Both descriptive and statistical data were manipulated and presented.

The instrument for this study was tested by calculating the Cronbach's alpha coefficient, which confirmed the alpha reliability and validity of the data collection instrument. The Cronbach's alpha score was $81 \%$, which revealed a very reliable instrument. The instrument reliability for the Cronbach's alpha coefficient test is typically estimated between 0.00 and 1.00; a test result from 0.70 to 1.0 (or above $70 \%$ ) is acclaimed by scholars as reasonably feasible for data collection (DeVellis 2003; Nunnally 1978).

\section{Discussion and analysis}

This section discusses the findings of the study beginning with the list of airlines that constitute South African owned airlines (Table 1) and the socio-demographic information of this study (Table 2).

About $44 \%$ of the study participants were male and $46 \%$ were female; $64 \%$ were Africans. $13.6 \%$ were mixed race, $9.8 \%$ Indian and $13.2 \%$ White.

\section{Hypothesis 1: Service quality and satisfaction}

In order to test hypothesis 1 , the respondents were asked to indicate their overall satisfaction rating of service quality among South African owned airlines. The results are depicted in Table 3.
TABLE 2: Socio-demographic information.

\begin{tabular}{lcc}
\hline Variables & Frequency & Percentage \\
\hline Gender & 312 & \\
Female & 372 & 45.6 \\
Male & 684 & 54.4 \\
Total & & 100 \\
Race & 434 & \\
African & 93 & 63.5 \\
Mixed race & 67 & 13.6 \\
Indian & 90 & 9.8 \\
White & $\mathbf{6 8 4}$ & 13.2 \\
\hline Total & & $\mathbf{1 0 0}$ \\
\hline
\end{tabular}

Source: Mantey (2015)

TABLE 3: Overall service quality satisfaction ratings of South African owned airlines.

\begin{tabular}{lccccc}
\hline Variables & \multicolumn{5}{c}{ Satisfaction ratings } \\
\cline { 2 - 6 } & Scale & Frequency & Percentage & $\begin{array}{c}\text { Valid } \\
\text { percentage }\end{array}$ & $\begin{array}{c}\text { Cumulative } \\
\text { percentage }\end{array}$ \\
\hline Very low & 1.0 & 9 & 1.3 & 1.3 & 1.3 \\
Low & 2.0 & 39 & 5.7 & 5.7 & 7.0 \\
Moderate & 3.0 & 284 & 41.5 & 41.5 & 48.5 \\
High & 4.0 & 321 & 46.9 & 46.9 & 95.5 \\
Very high & 5.0 & 31 & 4.5 & 4.5 & 100.0 \\
\hline Total & - & $\mathbf{6 8 4}$ & $\mathbf{1 0 0 . 0}$ & $\mathbf{1 0 0 . 0}$ & - \\
\hline Source & & & & &
\end{tabular}

Source: Mantey (2015)

Table 3 shows that $46.9 \%$ of the respondents rated satisfaction with service quality as high, while $41.5 \%$ rated it moderately satisfactory and $4.5 \%$ rated satisfaction with services as very high. Therefore, effectively $93 \%$ of the respondents were satisfied with the quality of the services offered by South African owned airlines despite gaps in service quality dimensions. Airline passengers' satisfaction with regard to service quality is common in the global industry. Therefore, the findings reflect the ultimate expectations of most airline passengers (Erdil \& Yildiz 2011:1232-1242; Wattanacharoensil \& Yoopetch 2012:280 $320)$. In the current era of customer-centric and value-added services provision to the customer, passenger-oriented quality service strategies that include rendering superior quality service (Gilbert \& Wong 2003:519-532) are crucial in order to maintain customers and sign up new passengers, thereby improving competitiveness and profitability (Erdil \& Yildiz 2011:1232; Wattanacharoensil \& Yoopetch 2012:286). Superior quality service thus cannot be neglected by airlines. Since the airline industry is about people, and ensuring that they fly in comfort, service quality should be one of the key elements in nurturing a sustainable industry. Indeed, airline companies allocate substantial financial resources to quality service delivery in order to satisfy customers, ultimately improving their revenue and profitability (Archana \& Subha 2012:51; Steven et al. 2012:743). Consequently, hypothesis H1 - there is general service quality satisfaction among passengers of South African owned airlines - is accepted in the light of the findings of this study and the literature.

\section{Hypothesis 2: Membership of loyalty programmes and air passengers' loyalty}

This hypothesis sought to determine if passengers' membership of a loyalty programme is an indication of their loyalty to South African owned airlines (Table 4). 
TABLE 4: Loyalty programme and passenger loyalty.

\begin{tabular}{lccccc}
\hline $\begin{array}{l}\text { Loyalty } \\
\text { programme }\end{array}$ & Frequency & Percentage & $\begin{array}{c}\text { Passenger } \\
\text { loyalty }\end{array}$ & Frequency & Percentage \\
\hline Yes & 151 & 22.1 & Yes & 586 & 85.7 \\
No & 533 & 77.9 & No & 98 & 14.3 \\
\hline Total & 684 & 100.0 & - & 684 & 100.0 \\
\hline
\end{tabular}

Source: Mantey (2015)

The results show that only $22 \%$ of the respondents were members of a loyalty programme and $78 \%$, were not. The results further reveal that $85.7 \%$ of the respondents were loyal passengers who consistently patronise a particular South African owned airline, while $14.3 \%$ were not. However, only $22 \%$ had signed up to loyalty programmes. Thus, while $78 \%$ were not part of a loyalty programme, $85.7 \%$ were loyal to the airline. This shows that membership of a loyalty programme is not necessarily an indication that a passenger is loyal to an airline. The results in Table 3 and Table 4 reveal that while the majority (93\%) of the respondents was satisfied with the level of service quality offered by South African airlines (Table 3), 78\% were not part of a loyalty programme, although $85.7 \%$ were loyal passengers (Table 4). The implication is that from a South African perspective, a passenger could be a loyal passenger and be satisfied with services (Table 3), but might not be a signed-up member of a loyalty programme. The key question is what makes South African domestic passengers loyal to airlines. This could be answered by more in-depth investigation.

Passengers may have various reasons to sign up or not sign up to loyalty programmes offered by South African owned airlines. From a marketing perspective, a loyalty programme aims to encourage consumers to support a brand's products and services with ongoing patronage (Berndt \& Brink 2004:25; Rai \& Medha 2013:141). The programmes offered by South African airlines have probably not satisfied customers' needs and expectations. There is thus a need for further research into the reasons why the majority of the study respondents were not part of a loyalty programme. It is possible that passengers were not satisfied with aspects of South African owned airlines service delivery and were therefore unenthusiastic about signing up for their loyalty programme. Conversely, it is possible that South African owned airlines have not adequately promoted their loyalty programmes. Other reasons could be that passengers do not see the need to join because of past unfulfilled promises (Pfeffer 2014:2). Furthermore, they might not be interested in any loyalty programme. Empirical research is required to draw conclusions on this phenomenon in the South African context. Thus, membership of a loyalty programme does not guarantee a passenger's loyalty to an airline. The hypothesis that passengers' membership of a loyalty programme does not guarantee their loyalty and patronage of South African owned airlines is thus supported by the empirical evidence and is accepted.

\section{Hypothesis 3: Effect of service quality gaps on passengers' loyalty and patronage}

Here the notion was to evaluate the effect of gaps in quality service delivery on passengers of South African owned
TABLE 5: Passenger loyalty statistics.

\begin{tabular}{lccccc}
\hline Variable & \multicolumn{5}{c}{ Group statistics } \\
\cline { 2 - 6 } & $\begin{array}{c}\text { Loyalty to } \\
\text { airlines }\end{array}$ & $\boldsymbol{N}$ & Mean $(\boldsymbol{M})$ & $\begin{array}{c}\text { Standard } \\
\text { deviation (SD) }\end{array}$ & $\begin{array}{c}\text { Standard } \\
\text { error mean }\end{array}$ \\
\hline Tangibility gap & Yes & 151 & 14.099 & 12.3222 & 1.0028 \\
score & No & 529 & 16.665 & 11.4183 & 0.4964 \\
Reliability gap & Yes & 151 & 12.152 & 8.3465 & 0.6792 \\
score & No & 529 & 12.917 & 7.8393 & 0.3408 \\
Responsiveness & Yes & 151 & 8.974 & 6.4663 & 0.5262 \\
gap score & No & 529 & 9.713 & 5.9126 & 0.2571 \\
Assurance gap & Yes & 151 & 7.755 & 5.3003 & 0.4313 \\
score & No & 529 & 8.414 & 5.0224 & 0.2184 \\
Empathy gap & Yes & 151 & 4.901 & 3.9846 & 0.3243 \\
score & No & 529 & 5.512 & 3.2730 & 0.1423 \\
\hline
\end{tabular}

Source: Mantey (2015)

airlines in the context of the SERVQUAL and the Gaps models (Lovelock \& Wirtz 2011:406; Parasuraman et al. 1985:41-50, 1988:12-40). The purpose was to determine the effect of these gaps on passengers' loyalty and patronage. Table 5 depicts the results.

With regard to loyalty programmes, the results show a gap score of tangibility $(M=14.099, \mathrm{SD}=12.3222)$, reliability $(M=$ $12.152, \mathrm{SD}=8.3465)$, responsiveness $(M=8.974, \mathrm{SD}=6.4663)$, assurance $(M=7.755, \mathrm{SD}=5.3003)$ and empathy $(M=4.901$, $\mathrm{SD}=3.9846)$. In respect of those passengers who were not part of a loyalty programme the gap score was: tangibility $(M=16.665, \mathrm{SD}=11.4183)$, reliability $(M=12.917, \mathrm{SD}=7.8393)$, responsiveness $(M=9.713, \mathrm{SD}=5.9126)$, assurance $(M=8.414$, $\mathrm{SD}=5.0224)$ and empathy $(M=5.512, \mathrm{SD}=3.2730)$. The Levene's test for Equality of Variances (Independent Samples Test) was conducted on the dimensional gaps and loyalty to further determine if there were significant gaps (Table 6).

There were significant gaps in the mean in the dimensional variables which were: tangibility (2.5661), reliability (-0.7645), responsiveness $(-0.7392)$, assurance $(-0.6590)$ and empathy $(-0.6116)$. While the respondents were generally satisfied (93\%) with South African owned airlines' services (Table 3), there were gaps in the services dimension variables (Table 5). The gap scores were tangibility $(M=14.099, \mathrm{SD}=12.3222)$, reliability $(M=12.152, \mathrm{SD}=8.3465)$, responsiveness $(M=$ $8.974, \mathrm{SD}=6.4663)$, assurance $(M=7.755, \mathrm{SD}=5.3003)$ and empathy $(M=4.901, \mathrm{SD}=3.9846)$. These gaps point to the fact that some aspects of service delivery quality by South African owned airlines were not totally satisfactory. Thus, further improvement is required. Airline service quality is dynamic as passengers constantly demand more services and improved service quality. This is problematic for airline companies from several perspectives (Lo et al. 2015:169). Management might find it difficult to identify passengers' exact requirements and assign financial resources to deliver exceptional services (Nikbin et al. 2015:340). The statistically insignificant values in the Levene's test for Equality of Variances (Independent Samples Test; see Table 6) on the relationship between the dimensional gaps and loyalty showed that there was no relationship. This means that dimensional gaps or the gaps in service delivery have no effect on passengers' loyalty and patronage of South African 
TABLE 6: Levene's test for Equality of Variances and loyalty programme.

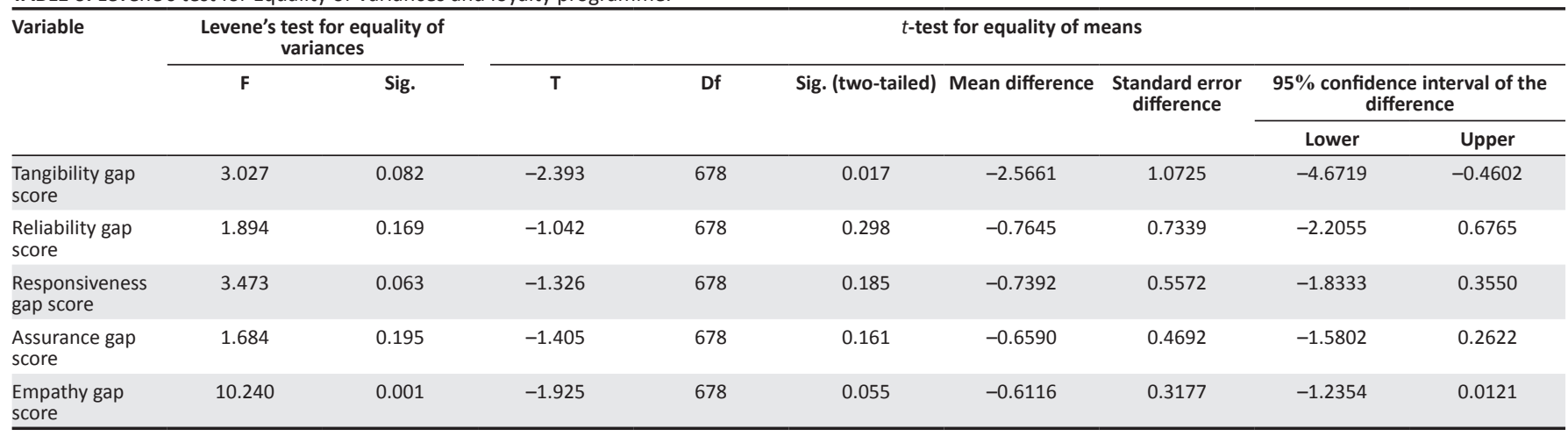

Source: Mantey (2015)

owned airlines. Therefore, $\mathrm{H} 3$, which stated that service quality gaps in South African owned airlines have no effect on passengers' loyalty and patronage, is accepted. The South African domestic airline market offers passengers limited choices and it is thus difficult to differentiate between airlines' services (Martin et al. 2008:200). Thus, whether services are satisfactory or unsatisfactory, passengers will patronise the airline because they have no alternative option (Mantey \& Naidoo 2016:330-356). However, the literature (Namukasa 2013:523; Rai \& Medha 2013:141) has linked customer service satisfaction to passenger loyalty. Rai and Medha (2013:141) state that loyalty is a psychological state developed through ongoing fulfilment of the customer's connection to a service firm, as a result of a long-standing relationship and patronage. Previous studies have shown that membership of a loyalty programme does not guarantee loyalty to a particular airline (Berndt \& Brink 2004:25; Rai \& Medha 2013:141).

\section{Hypothesis 4: Relationship between frequency of travel and loyalty programmes}

The dataset was reviewed to establish the association between loyalty programmes and frequency of travel (Table 7).

The results show that $66 \%$ of the respondents had travelled frequently within the past 12 months, on both domestic and international flights. Over the past 13-24 months, only $24 \%$ had travelled frequently, while $9 \%$ had travelled frequently for over 36 months.

\section{Inferential statistics}

Using inferential statistics and cross-tabulation, of those not signed up to a loyalty programme, $83 \%$ had travelled frequently for up to12 months, compared with only $17 \%$ of those on a loyalty programme $(p<0.01)$ (Table 8$)$.

Although, more than a fifth $(22 \%)$ of the participants were part of a loyalty programme, a large percentage (almost $78 \%$ ) were not on a loyalty programme (Table 7). Reviewing the inferential statistics (Table 8), it was established that a loyalty programme was not associated with frequent travel. Significant association could not be established in the variables. The hypothesis $\mathrm{H} 4$, there is no significant
TABLE 7: Frequency of travel.

\begin{tabular}{lcc}
\hline Frequent travel & Frequency & Percentage \\
\hline $0-12$ month & 452 & 66.1 \\
$13-24$ months & 166 & 24.3 \\
$25-36$ months & 29 & 4.2 \\
$>36$ months & 37 & 5.4 \\
\hline Total & 684 & 100.0 \\
\hline
\end{tabular}

Source: Mantey (2015)

association between passengers' travel frequency and the loyalty programmes offered by South African owned airlines is accepted. It cannot be concluded that frequent travel will lead to passenger loyalty to an airline. Nor can one hold that frequent travel induces passengers to sign up for a loyalty programme (Dolnicar et al. 2011:1020), although frequent travel accumulates points, which can be redeemed by the passenger, depending on airline's terms and conditions. Terblanche (2015:200) notes that in the services industry, including airlines, if customers are satisfied with the services they receive, they consolidate their purchasing arrangements and loyalty to that firm, while also providing positive word-of-mouth information about the service provider to potential customers. The opposite holds true if customers are dissatisfied as they are likely to switch patronage and loyalty (Berndt \& Brink 2004:25).

\section{Ethical consideration}

This study was conducted in compliance with the University of KwaZulu-Natal's research ethics requirements of anonymity, confidentiality, independent work and plagiarism. These tenets were maintained throughout this study.

\section{Implications}

Theoretically, this study provides new insight into service quality from the South African perspective. This fills a research gap as few studies have investigated airline service quality in this country. Service quality in the airline industry is a complex phenomenon as passengers' expectations differ. However, it is of crucial importance to the survival and progress of this industry. Excellent service quality ensures that passengers receive value for money. Thus, airlines would do well to take heed of their passengers' expectations (Mantey 2015:1-433). 
TABLE 8: Loyalty programme and frequency of travel (cross-tabulation).

\begin{tabular}{|c|c|c|c|c|c|c|c|c|c|c|}
\hline \multirow{3}{*}{$\begin{array}{l}\text { Loyalty } \\
\text { programme }\end{array}$} & \multicolumn{8}{|c|}{ Frequent travel } & \multirow{2}{*}{\multicolumn{2}{|c|}{ Total }} \\
\hline & \multicolumn{2}{|c|}{ 0-12 months } & \multicolumn{2}{|c|}{ 13-24 months } & \multicolumn{2}{|c|}{ 25-36 months } & \multicolumn{2}{|c|}{$>36$ months } & & \\
\hline & Count & $\begin{array}{c}\% \text { within frequent } \\
\text { travel }\end{array}$ & Count & $\begin{array}{c}\% \text { within } \\
\text { frequent travel }\end{array}$ & Count & $\begin{array}{l}\% \text { within } \\
\text { frequent travel }\end{array}$ & Count & $\begin{array}{c}\% \text { within } \\
\text { frequent travel }\end{array}$ & Count & $\begin{array}{c}\% \text { within } \\
\text { frequent travel }\end{array}$ \\
\hline Yes & 77 & 17. & 52 & 31.3 & 11 & 37.9 & 11 & 29.7 & 151 & 22.1 \\
\hline No & 375 & 83.0 & 114 & 68.7 & 18 & 62.1 & 26 & 70.3 & 533 & 77.9 \\
\hline Total & 452 & 100.0 & 166 & 100.0 & 29 & 100.0 & 37 & 100.0 & 684 & 100.0 \\
\hline $\begin{array}{l}\text { Chi-square } \\
\text { tests }\end{array}$ & \multicolumn{10}{|c|}{$\mathrm{X}^{2}=20.429, \mathrm{df}=3, p<0.01$} \\
\hline
\end{tabular}

Source: Mantey (2015)

From a managerial perspective, excellent service provides competitive advantage; increases market share and profitability and promote passenger loyalty and patronage (Namukasa 2013:530). From a strategic marketing perspective, this study provides cognitive information, which management could use to design new marketing strategies to enhance loyalty. The benefits promised to passengers should always be delivered and CRM should be a priority. The service excellence vision should be propelled by efficient CRM systems. Information communication technologies (ICT) combined with CRM systems creates a repository of information on passengers' business and customer relationships with South African owned airlines. If this information is properly used, it could assist airlines to offer personalised service that meets passengers' requirements (Mantey 2015:70; Wang, Park \& Fesenmaier 2012:371).

The findings of this study imply that South African owned airlines should intensify their campaigns to encourage passengers to participate in loyalty programmes in order to sustain patronage. At the same time, they should educate passengers on the benefits of such programmes. Such benefits should be well defined and concisely communicated. Promises should always be fulfilled. However, loyalty programmes should be linked to exceptional service quality, which is fundamental in heightening and sustaining passengers' loyalty (Chikwendu et al. 2012:117-126; Namukasa 2013:530).

\section{Recommendations}

Based on the study's findings, the following recommendations are made to management of South African owned airlines as per Table 9.

\section{Limitations and future research}

This study relied on quantitative information collated from the South African environment; therefore, the study cannot be generalised for the entire global airline industry. However, the empirical evidence has provided some insight into service quality, passengers' satisfaction and loyalty with regard to South African owned airlines.

Future research could investigate the causes of the unenthusiastic response to loyalty programmes in South Africa. Are these programmes beneficial to passengers, do they really receive value from such programmes and what
TABLE 9: Summary of recommendations.

\begin{tabular}{ll}
\hline No. & Recommendation \\
\hline 1 & $\begin{array}{l}\text { Management of South African owned airlines should strive to improve } \\
\text { service quality to passengers. }\end{array}$ \\
\hline 3 & $\begin{array}{l}\text { South Africa owned airlines should publicise their loyalty programmes. } \\
\text { Passengers should be made aware of the benefits of subscribing to loyalty } \\
\text { programmes. }\end{array}$ \\
\hline 4 & $\begin{array}{l}\text { Since membership of a loyalty programme is not indicative of passenger } \\
\text { loyalty, management needs to win the hearts and minds of passengers. } \\
\text { One of the main ways to do so is to offer top quality service. }\end{array}$ \\
& $\begin{array}{l}\text { Like all customers, South African airline passengers expect high-quality } \\
\text { services. Delivering such services should thus be the cardinal ambition of } \\
\text { South African owned airlines; therefore, management should strategically } \\
\text { work towards this ambition. }\end{array}$ \\
6. & $\begin{array}{l}\text { Management should make a conscious effort to close or completely } \\
\text { eliminate service delivery gaps. This would enhance service quality and } \\
\text { induce passengers' loyalty and patronage. }\end{array}$ \\
\hline
\end{tabular}

Source: Mantey (2015)

are the intrinsic benefits? Further research could also be conducted on customer and passenger relationship management, probing the extent to which South African owned airlines are aware of passengers' requirements and attempt to meet such needs.

\section{Conclusion}

Based on the study's results, it is concluded that service quality is of paramount importance to an air passenger. Consequently, excellent service quality, which promotes passenger loyalty and patronage, is the key to the survival, competitiveness, sustainability and profitability of South African owned airlines. The interplay between service quality, satisfaction and loyalty offers South African owned airlines opportunities to provide satisfactory service to their passengers. While loyalty programmes may be beneficial to the passenger provided the airline is sincere and faithful to the tenets of the programme, ultimately, the passenger expects service excellence and satisfaction. An airline with a broad, loyal passenger base has a sustainable future. South African owned airlines should thus design systems to identify their loyal passengers and handsomely reward them for continuous patronage. This would enable them to gain competitive advantage, increasing overall profitability.

\section{Acknowledgements}

We would like to acknowledge the School of Management, Information Technology and Governance, University of KwaZulu-Natal, Durban, for allowing us access to its computer resources to prepare this article. 


\section{Competing interests}

The authors of this article do hereby affirm that this article was written purely for academic purposes and they have not been influenced by any person(s) or organisation(s) for financial gains.

\section{Authors' contributions}

N.O.M. was responsible for conducting this study. V.N. was responsible for supervising the study and providing guidance.

\section{References}

Airports company of South Africa (ACSA), 2014, Annual reports, viewed 15 June, 2015, from http://www.acsa.co.za/FinancialResults/2014\%20Integrated $\% 20$ Annual\% 20Report $\% 202014 . p d f$

Ahadmotlaghi, E. \& Pawar, P., 2012, 'Analysis of CRM programs practiced by passengers', airline industry of India, and its impact on customer satisfaction and loyalty', Journal of Arts, Science, and Commerce 3(2), 2-5.

Archana, R. \& Subha, M.V., 2012, 'A study on service quality and passenger satisfaction on Indian airlines', International Journal of Multidisciplinary Research 2(2), 50-63.

Baker, D.M.C., 2013, 'Service quality and customer satisfaction in the airline industry: A comparison between legacy airlines and low-cost airlines', American Journal of Tourism Research 2(1), 67-77. https://doi.org/10.11634/216837861302317

Battaglia, M. \& Lavrakas, P.J., 2013, Encyclopedia of survey research methods, convenience sampling, Sage Research Methods, Teller Road, Thousand Oaks, California.

Berndt, A. \& Brink. A., 2004, Customer relationship management and customer service, Juta, Lansdowne, South Africa.

Campbell, B. \& Vigar-Ellis, D., 2012, 'The importance of choice attributes and the positions of the airlines within the South African domestic passenger airline industry as perceived by passengers at Durban International Airport', Southern African Business Review 16(2), 97-119.

Chen, P.-T. \& 'Sunny' Hu H.-H. (2013). 'The mediating role of relational benefit between service quality and customer loyalty in airline industry', Total Quality Management and Business Excellence, 24:9-10, 1084-1095. https://doi.org/10.10 $80 / 14783363.2012 .661130$

Chikwendu, D.U., Ejem, E. \& Ezenwa, A., 2012, 'Evaluation of service quality of Nigerian airline using SERVQUAL model', Journal of Hospitability Management and Tourism 3(6), 117-126. https://doi.org/10.5897/JHMT12.019

De Meyer, C.F. \& Mostert, P.G., 2011, 'The influence of passenger satisfaction on relationship formation in the South African domestic airline industry', South African Journal of Business Management 4, 42-79.

Devellis, R.F., 2003, Scale development: Theory and applications, 2nd edn., Sage, Thousand Oaks, CA.

Dolnicar, S., Grabler, K., Grun, B. \& Kulnig, A., 2011, 'Key drivers of airline loyalty', Tourism Management 32(5), 1020-1026. https://doi.org/10.1016/j. tourman.2010.08.014, PMid:27064618. PMCid:PMC4802509.

Duchessi, P. (2002). Crafting customer value: The art and science. Purdue University Press, USA.

Erdil, S. \& Yildiz, O., 2011, 'Measuring service quality and comparative analysis in the passenger carriage of the airline industry', Procedia Social and Behavioural Science 24, 1232-1242. https://doi.org/10.1016/j.sbspro.2011.09.117

Fitzsimmons, J.A. \& Fitzsimmons, M.J., 2011, Service management: Operations, strategy, information technology, 7th edn., McGraw Hill, New York.

Gilbert, D. \& Wong, R.K.C., 2003, 'Passenger expectations and airlines: A case of Hong Kong-based study', Tourism Management 24, 519-532. https://doi.org/10.1016/ S0261-5177(03)00002-5

Harrison A. \& Van Hoek, R., 2011, Logistics management \& strategy competing through the supply chain, 4th edn., Pearson, England.

Johnson, M., Sivadas, E. \& Garbarino, E., 2008, 'Customers satisfaction, perceive risk and affective commitment', Journal of Services Marketing 22, 353-362. https:// doi.org/10.1108/08876040810889120

Kotler, P. \& Keller, K.L., 2012, Marketing management, 14th edn., Pearson, Essex, England.

Keller, K.L., 2013, Building measuring, and managing brand equity, 4th edn., Pearson, Essex, England.

Ladhari, R. (2009), 'A review of twenty years of SERVQUAL research', International Journal of Quality and Service Sciences 1(2), 172-198. https://doi. org/10.1108/17566690910971445

Lo, A.S., Wu, C. \& Tsai, H., 2015, 'The impact of service quality on positive consumption emotions in resort and hotel spa experiences', Journal of Hospitality Marketing \& Management 24(2), 155-179. https://doi.org/10.1080/19368623.2014.885872

Lovelock, C. \& Wirtz, J., 2011, Services marketing people, technology, strategy, 7th edn., Pearson, NJ.
Luke, R. \& Walters, J., 2013, 'Overview of the developments in the domestic airline industry in South Africa since market deregulation', Journal of Transport \& Supply Chain Management 7(1), 1-11. https://doi.org/10.4102/jtscm.v7i1.117

Mantey, N.O., 2015, Passengers' perceptions and expectations towards service quality of airlines owned by South Africa, University of KwaZulu-Natal, Durban.

Mantey, N.O. \& Naidoo, V., 2016, 'Evaluation of passengers' perceptions on service quality in South African owned airlines', Journal of Contemporary Management 13, 330-356.

Martin, J.C., Roman, C. \& Espino, R., 2008, 'Willingness to pay for airline service quality, transport reviews', A Transnational Transdisciplinary Journal 28(2) 199-217. https://doi.org/10.1080/01441640701577007

Metters, R.D., King-Metters, K.H., Pullman, M. \& Walton, S., 2006, Successful service operations management, 2nd edn., Thomson, NY. PMCid:PMC1458941.

Mohan, S., Choi, E., \& Min, D. (2008). 'Conceptual modeling of enterprise application system using social networking and Web 2.0 "social CRM system"', paper
presented at 2008 International Conference on Convergence and Hybrid Information Technology, Busan, Korea, 11-13 November. https://doi.org/10.1109/ Information Techno
ICHIT.2008.263

Mostert, P.G, de Meyer, C.F. \& Van Rensburg, L.R.J., 2009, 'The influence of service failure and service recovery on airline passengers' relationships with domestic airlines: An exploratory study', Southern African Business Review 13(2), 118-140.

Naidoo, V., 2015, 'A comparative study between staff and student perceptions of service quality', Journal of Contemporary Management 12, 40-60.

Naidoo, V. \& Mutinta, G., 2014, 'An investigation into service quality delivery at the University of KwaZulu-Natal', Journal of Social Sciences 38(3), 219-229.

Namukasa, J., 2013, 'The influence of airline service quality on passenger satisfaction and the loyalty: The case of Uganda airline industry', The TQM Journal 25(5), 520532. https://doi.org/10.1108/TQM-11-2012-0092

Naumann, P.W.E., 2011, 'Customer satisfaction and business performance: A firmlevel analysis', Journal of Service Marketing 25(1), 20-32. https://doi. org/10.1108/08876041111107032

Nikbin, D., Marimuthu, M., Hyun, S.S. \& Ismail, I., 2015, 'Relationships of perceived justice to service recovery, service failure attributions, recovery satisfaction, and loyalty in the context of airline travelers', Asia Pacific Journal of Tourism Research 20(3), 239-262. https://doi.org/10.1080/10941665.2014.889028

Nunnally, J.C., 1978, Psychometric theory, 2nd edn., McGraw Hill, New York.

Pakdil, F. \& Aydin, O., 2007, 'Expectation and perceptions in airline services: An analysis using weighted SERVQUAL scores', Journal of Air Transportation Management 13, 229-237. https://doi.org/10.1016/j.jairtraman.2007.04.001

Parasuraman, A., Zeithaml, V.A. \& Berry, L.L., 1985, 'A conceptual model of service quality and its implications for future research', Journal of Marketing 49(4), 4150. https://doi.org/10.2307/1251430

Parasuraman, A., Zeithaml, V. \& Berry, L.L., 1988, 'SERVQUAL: A multiple-item scale for measuring consumer perceptions of service quality', Journal of Retailing 64, 12-40.

Park, J.-W., Robertson, R. \& Wu, C.-L.., 2004, 'The effect of airline service quality on passengers' behavioural intentions: A Korea case study', Journal of Air Transport Management 10(6), 435-439. https://doi.org/10.1016/j.jairtraman. Transport Mana
2004.06.001

Pfeffer, J, 2014, How airline loyalty programs seduce and abandon you, viewed 04 September, 2016, from http://fortune.com/2014/10/01/airline-loyalty-programs

Piercy, N., 2009, Market-led strategic change, 4th edn., Butterworth-Heinemann, Oxford, United Kingdom. PMCid:PMC2728091.

Rai, A.K. \& Medha, S., 2013, 'The antecedents of customer loyalty: An empirical investigation in life insurance context', Journal of Competitiveness 5(2), 139-163. https://doi.org/10.7441/joc.2013.02.10

Reinartz, W. \& Kuma, V., 2002, 'The mismanagement of customer loyalty', Harvard Business Review 80(7), 86-94.

Sahney, S., Banwet, D.K. \& Karunes, S., 2004, 'An SERVQUAL and QFD approach to total quality education: A student perspective', International Journal of Productivity and Performance Management 53(2), 143-166. https://doi. org/10.1108/17410400410515043

Schneider, B. \& White, S.S., 2004, Service quality research perspectives, foundation for organizational science, SAGE, Thousand Oaks, CA.

Sekaran, U. \& Bougie, R., 2013, Research methods for business-skill-building approach, 6th edn., John Wiley, The United Kingdom.

Shahin, A., 2006, SERVQUAL and model of service quality gaps: A framework for determining and prioritizing critical factors in delivering service quality, Department of the Management, University of Isfahan, Isfahan, Iran.

Siu, N.Y.M., Zhang, T.J.F. \& Yau, C.Y.J., 2013, 'The roles of justice and customer satisfaction in customer retention: A lesson from service recovery', Journal of Business Ethics 114, 675-686. https://doi.org/10.1007/s10551 013-1713-3

Steven, A.B., Dong, Y. \& Dresdner, M., 2012, 'Linkages between customer service, customer satisfaction and performance in the airline industry: Investigation of non-linearity and moderating effects', Transportation Research Part E 48, 743-754. https://doi.org/10.1016/j.tre.2011.12.006

Terblanche, N.S., 2015, 'Customers' perceived benefits of a frequent flyer program' Journal of Travel \& Tourism Marketing 32(3), 199-210. https://doi.org/10.1080/1 0548408.2014.895694

Urban, G.L., 2004, 'The emerging era of customer advocacy', Sloan Management Review 45, 77-82. 
Van Iwaarden, J., van der Wiele, T., Ball, L. \& Millen, R. (2003). 'Applying SERVQUAL to websites: An exploratory study. International Journal of Quality and Reliability Management 20(8), 919-935. https://doi.org/10.1108/02656710310493634

Wang, D., Park, S. \& Fesenmaier, D.R., 2012, 'The role of smart phones in mediating the touristic experience', Journal of Travel Research 51(4), 371-387. https://doi. org/10.1177/0047287511426341

Wang, R., Hsu, S.L., Lin, Y.H. \& Tseng, M.L., 2011, 'Evaluation of customer perceptions on airline service quality in uncertainty', Procedia - Social and Behavioural Sciences 25, 419-437. https://doi.org/10.1016/j.sbspro.2012.02.054
Wattanacharoensil, W. \& Yoopetch, C., 2012, 'Thailand's human resource competencies in airline service quality: Voices from the airline industry', Journa of Human Resources in Hospitality and Tourism 11(4), 280-320. https://doi.org/ 10.1080/15332845.2012.690680

Wisniewiski, M., 2001, 'Using SERVQUAL to assess customer satisfaction with public sector services', Managing Service Quality 11(6), 380-388. https://doi. org/10.1108/EUMOO000000006279

Zeithaml, V.A., Bitner, M.J. \& Gremler, D.D., 2006, Services marketing, 4th edn., McGraw-Hill, Boston, MA. 